\title{
Flexural Properties of Heat-Treatment Samama (Anthocephalus macrophyllus) Wood Impregnated by Boron and Methyl Metacrylate ${ }^{1}$
}

\author{
Tekat Dwi CAHYONO ${ }^{2, \dagger} \cdot$ Wayan DARMAWAN ${ }^{3}$ • \\ Trisna PRIADI $^{3}$ • Apri Heri ISWANTO ${ }^{4}$
}

\begin{abstract}
This study was conducted to analyze the application of boron compounds, methyl methacrylate (MMA), and heat treatment (HT) on changes in the density, moisture content, and flexural properties of samama (Anthocephalus macrophyllus) wood. Samama wood was impregnated with borax (BX) and boric acid (BA) using a pressure method at $5 \mathrm{~atm}$ for $4 \mathrm{~h}$. Afterwards, the wood was impregnated with MMA at the same pressure and duration. Finally, the samama wood was given $\mathrm{HT}$ at $90{ }^{\circ} \mathrm{C}$ and $180{ }^{\circ} \mathrm{C}$. The results indicate that there was a weight gain of $93.4 \%$ in the wood impregnated using BA and MMA monomer and HT at $90{ }^{\circ} \mathrm{C}$. Consequently, the wood's density increased by $82.3 \%$. Increased MOE and MOR percentages of $32.2 \%$ and $29.4 \%$, respectively, were also found. $\mathrm{HT}$ at $180{ }^{\circ} \mathrm{C}$ degraded the wood components and MMA, and consequently, the density, MOE, and MOR also decreased. The wood impregnated by BX, BA, and MMA, and subjected to HT also had decreased moisture content (MC). This research recommends that the application of boron (BX, BA) should be combined with an MMA monomer and $\mathrm{HT}$ at $90{ }^{\circ} \mathrm{C}$ as an alternative method to improve samama wood quality. If darker color is preferable, HT should be conducted at $180{ }^{\circ} \mathrm{C}$.
\end{abstract}

Keywords: boron, heat treatment, impregnation, methyl metacrylate, Samama wood

\section{INTRODUCTION}

Boron had long been used to preserve wood and for its ability to retard the fire. Wang et al. (2005) explained that the application of phosphor-nitrogen and boron solutions was highly effective in increasing the fire retardant in woods and composite products. Meanwhile, according to Hadi et al. (2007), wood preser- vation using borax 5\% had a better durability properties than chemically modified woods with acetylation and wood fumigation. Judging from the types of wood used, those from hardwood and softwood groups had their preservation increased after being impregnated with boron (Simsek et al., 2010; Perçin et al., 2015). Thus, a type of wood with low specific gravity, coming from fast-growing plants, endemic in eastern part of

\footnotetext{
${ }^{1}$ Date Received June 14, 2019, Date Accepted January 8, 2020

${ }^{2}$ Faculty of Agriculture, University of Darussalam Ambon, Batu Merah, Ambon 97128, Indonesia

${ }^{3}$ Department of Forest Products, Faculty of Forestry, IPB University, Bogor 16680, Indonesia

${ }^{4}$ Department of Forest Product, Faculty of Forestry, Universitas Sumatera Utara, Padang Bulan, Medan 20155, Indonesia

† Corresponding author: Tekat Dwi CAHYONO (e-mail: tekatdwicahyono@gmail.com, ORCID: 0000-0002-3010-7656)
} 
Flexural Properties of Heat-Treatment Samama (Anthocephalus macrophyllus) Wood Impregnated by Boron and Methyl Metacrylate

Indonesia, such as Samama (Anthocephalus macrophyllus) had the potential for its preservation to be increased with boron. This was confirmed by the previous study results on Samama wood quality (Cahyono et al., 2015; Cahyono et al., 2016), some of its chemical properties and durability (Cahyono et al., 2012).

Boron compound was highly effective in increasing wood durability. The only weakness was that this compound was easily vanished while being used, thus decreased its effectiveness after a few years (Kartal et al., 2008). Various methods had been employed to improve the fixation of boron, including by adding coating to a wood surface. Applying a layer to a surface with nitrocellulose was effective to protect boron compound from a leaching process (Mohared et al., 2002). However, it might be said that applying a layer to a surface to maintain Boron was not too effective, particularly after three years. This was because boron compound might be diffused when the moisture content exceeds $20 \%$, despite the coating applied to its surface (Sites and Williams, 1997).

In addition to the surface modification technique, maintaining boron inside a wood might be done by adding water repellent or polimerizable monomers. Kartal et al. (2004) applied disodium octoborate tetrahydrate (DOT) to woods, using allyl glycidyl ether (AGE) in combination with methylmethacrylate (MMA) and heat treatment at $100{ }^{\circ} \mathrm{C}$ (4 hours). Yalinkilic et al. (1998) used Borax (BX), MMA and polimerization at lower temperature, i.e. $90{ }^{\circ} \mathrm{C}$ (4 hours). Other monomers which hadbeen used in a previous study included polyglycerol/ maleic anhydride adduct and polyglycerol metharcrylate (Salman et al., 2014). With their strengths and weaknesses, these monomers might improve the fixation of boron inside the wood.

The main approach of chemical modification to maintaining boron inside a wood was tightly related with leachability test and dimensional stabilization increase. On the contrary, not many studies had pre- sented the effect of boron treatment on flexural properties. Meanwhile, one of the purposes of preservation was for structural use within a planned period of time. Previous studies presenting the mechanical properties were limited to borax and heat treatments (Awoyemi and Westermark, 2005; Kartal et al., 2008; Perçin et al., 2015). Therefore, what this first paper presents focused on flexural properties of Samama wood after being impregnated with borax, MMA and heat treatment. The change in color, dimensional stabilization and resistance to biological deterioration might be presented in the second part script.

\section{MATERIALS and METHODS}

\subsection{Material preparation}

The wood used in this research was Samama wood from the community forest in Bogor, West Java. The plant was 9 years old and 3 plants free of any defect with straight trunk are chosen. The plants were then cut down and brought to the laboratory in fresh condition. The test sample was taken from the log at $50 \mathrm{~cm}$ from the land and it was then made into boards at

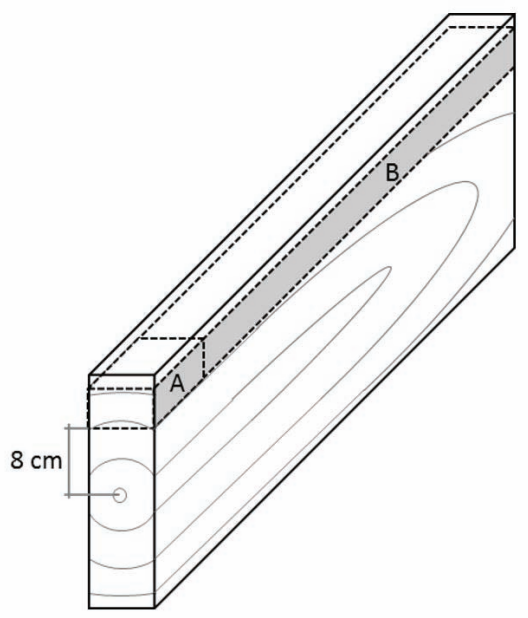

Fig. 1. Illustration of test sampling $(\mathrm{A}=$ test sample for physical properties, $\mathrm{B}=$ flexural properties). 
$7 \mathrm{~cm}$ thick. The illustration of sampling was presented in Fig. 1. The boards were then dried using kiln drying at $40{ }^{\circ} \mathrm{C}$ until the moisture content reaching $10-12 \%$. Furthermore, test samples were made as needed. The test sample was taken $8 \mathrm{~cm}$ from the pith to ensure that the part was mature wood (Cahyono et al., 2015).

\subsection{Impregnation process using boron and methylmetacrylate polimerization}

The boron solution used in this research was Borax (Sodium tetraborate decahydrate) and Boric Acid (Trihydrooxidoboron). Both were separately impregnated into different test samples with the concentration of each $5 \%$. The impregnation used pressure wood treatment equipment while the pressure applied was $5 \mathrm{~atm}$ for 4 hours. After being pulled out of the pressure tank, it was then followed by measuring the weight and drying the test sample to the air dry condition. The next step was impregnation with MMA using Mepoxi M (Methyl Ethyl Ketone Peroxide) as a catalyst at 10:1 ratio (v/v). The pressure applied was the same as the impregnation process with Borax and Boric Acid, i.e. 5 atm, for 4 hours. After being taken out of the press tube, the test sample was drained, wrapped with aluminium foil and it was followed with heat treatment (HT). The temperatures used were $90{ }^{\circ} \mathrm{C}$ and $180{ }^{\circ} \mathrm{C}$ (for 4 hours respectively). The test sample was then put into a desiccator and oven back at $103 \pm 3{ }^{\circ} \mathrm{C}$ in order to obtain the oven dry weight upon treatment.

\subsection{Mass change, density and moisture content}

The change in test sample weight showed the test sample weight differences before and after treatment. The density was measured in two conditions, i.e. during air-dry (AD) and oven-dry (OD). The air-dry density was the comparison between weight and volume in airdry condition and oven-dry density was obtained by comparing the weight and volume in oven-dry condition (Bowyer et al., 2007). The test samples' length, width, and thickness were $2 \mathrm{~cm} \times 2 \mathrm{~cm} \times 2 \mathrm{~cm}$. The moisture content was obtained from the percentage of comparison between test sample's water weight and oven-dry weight (ASTM, 2010).

\subsection{Modulus of Elasticity (MOE) and Modulus of Rupture (MOR)}

The test sample was $2 \mathrm{~cm} \times 2 \mathrm{~cm} \times 30 \mathrm{~cm}$, placed in the Instron 4449 universal testing machine at a span length of $28 \mathrm{~cm}$. The loading was done in tangential direction using one point loading method. The magnitude of load and the resulting deflection were then shown in a graph. This comparison was also used for calculating the value of flexural properties (MOE and MOR) (JAS, 2003).

\subsection{Data analysis}

The data was analyzed using factorial method in a completely randomized design. The first factor was boron application in three levels, namely $0 \%$, borax (BX) $5 \%$ and boric acid (BA) 5\%. The second factor was MMA monomer application consisting of two levels, namely $0 \%$ and $100 \%$. The third factor was heat treatment which used two temperature levels, namely $90{ }^{\circ} \mathrm{C}$ and $180^{\circ} \mathrm{C}$. Each test sample was repeated 5 times. If the analysis found a significant influence, then it was followed with Duncan test at 5\% level.

\section{RESULTS and DISCUSSION}

\subsection{Mass change}

The process of inserting a material into wood results in weight change. Figs. 2 and 3 presented the weight changes of test sample before and after treatment. BX and BA impregnations were only at $5 \%$, thus the increase 
Flexural Properties of Heat-Treatment Samama (Anthocephalus macrophyllus) Wood Impregnated by Boron and Methyl Metacrylate

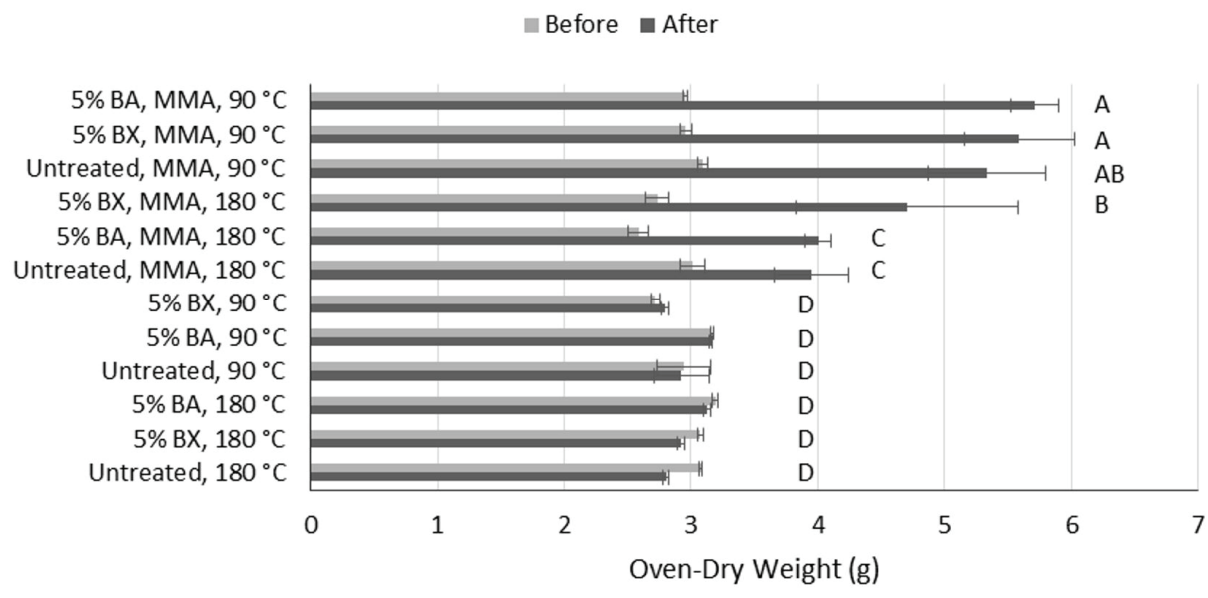

Fig. 2. Change of oven-dry mass before and after Treatment.

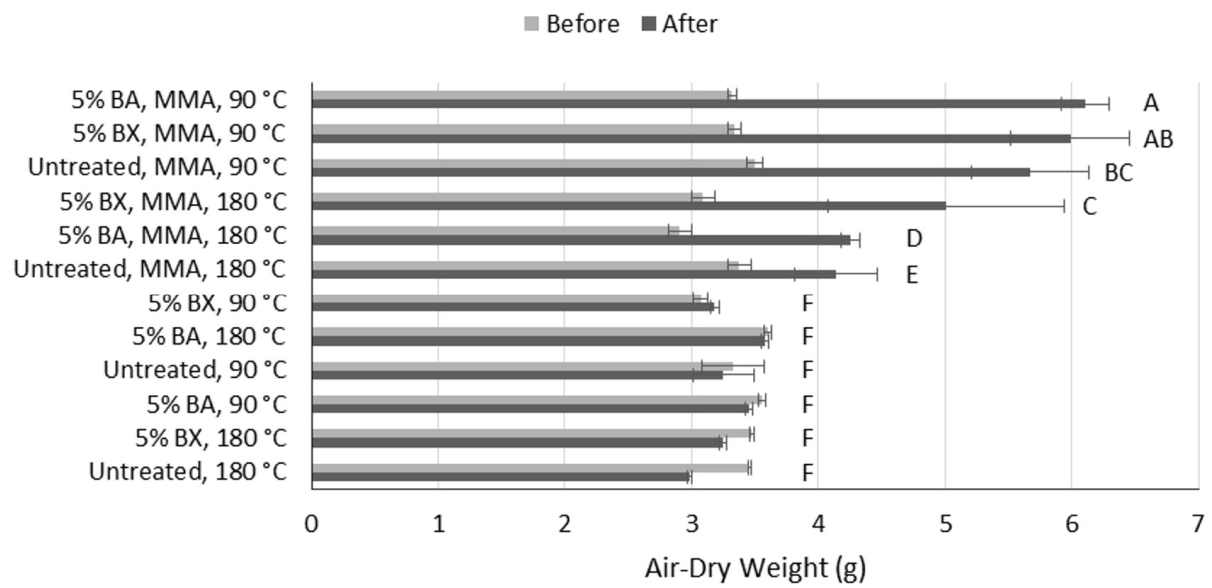

Fig. 3. Change of air-dry mass before and after Treatment.

percentage lay in 5\% range. After being combined with MMA, the mean weight gain reached up to $93.4 \%$ and 83.8\% in $\mathrm{OD}$ and $\mathrm{AD}$ conditions respectively. This highest mean value occurred in Samama wood which was given by BA, MMA monomer and heat treatment at $90{ }^{\circ} \mathrm{C}$. After $\mathrm{HT}$ at $180{ }^{\circ} \mathrm{C}$, test sample weight loss was seen, particularly in the test sample which used MMA monomer. This was seen from the wider weight difference between the test sample given with heat treatment 90 and $180{ }^{\circ} \mathrm{C}$.
The heat treatment in this research was used for two purposes, firstly for monomer polymerization and secondly for potentially improving the wood quality, including the potential of retaining the boron compound fixation inside the wood. After heat treatment, the wood weight change seemed to be more complex. It was because the heat treatment degraded the wood components. The higher the temperature used, the more likely the wood to degrade (losing its weight further). Previous studies found that heating at $220{ }^{\circ} \mathrm{C}$ produced the 
greatest weight loss (Chaouch et al., 2010, Salman et al., 2014). On the contrary, in treatment at lower temperatures, i.e. at $150{ }^{\circ} \mathrm{C}$ and $180{ }^{\circ} \mathrm{C}$, the change was inconsistent, sometimes it decreased and increased (Esteves and Pereira, 2008; Salman et al., 2014; Priadi et al., 2019).

The Samama wood weight changes after heat treatment (HT) at $180{ }^{\circ} \mathrm{C}$ were identical between the test sample administered and not administered with monomer. This meant even after being impregnated with MMA, Samama wood also under went weight loss due to heat treatment. After HT, it was suspected that monomer was also degraded since it lost its weight quite significantly. The proof was the smaller weight difference when compared to the test samples without HT, maximally only $62.2 \%$ and $72.1 \%$ within $\mathrm{AD}$ and OD condition. Analysis of variance showed that the impregnation of MMA, HT and interaction between MMA and HT influenced the Samama wood weight lost $(p$ value $=0.000)$, both in $\mathrm{AD}$ and $\mathrm{OD}$ condition. Kartal et al. (2008) explained that the chemical component degraded during the heat treatment was hemicellulose, and on the contrary the lignin klason increased. Additionally, the wood acidity decreased (Awoyemi and Westermark, 2005) as a result of organic acid loss, particularly acetic acid (Kartal et al., 2008). Both statements confirmed that the degraded one was the wood component and their studies were without monomer.

Boron might prevent Samama wood from losing its weight due to heat treatment. This was seen from the higher weight loss as compared to the test sample with no boron, both in $\mathrm{OD}$ and $\mathrm{AD}$ conditions. The same happened to the test sample impregnated with monomer. When BX was compared to BA, then BX had a better ability in preventing weight loss than BA. This phenomenon was supported by the research conducted by Salman et al. (2014). The cause was the buffering effect of borax-limiting acid catalyzed degradation of wood due to the liberation of low molecular weight carboxylic acid like acetic or formic acid during wood degradation.

\subsection{Density change}

The density change was tightly related to the weight and dimension variations. During the Samama wood impregnation process, the wood volume potentially developed since the cell wall was fully filled with impregnants, particularly MMA monomer. On the contrary, HT process degraded the wood component and decreased both its weight and volume at the same time. The role that the impregnants played in this phenomenon was to prevent the wood weight and dimension changes, thus the density decrease effect was lessened.

Table 1 showed Samama density changed before and after preservation process. Nearly all test samples showed a density increase after impregnation process, particularly those added with MMA monomer. The highest density increase occurred in the test sample impregnated with BA, monomer and at $90{ }^{\circ} \mathrm{C}$. The increases were by $79.6 \%$ and $82.3 \%$ for $\mathrm{AD}$ and $\mathrm{OD}$ respectively. After $\mathrm{HT}$ at $180{ }^{\circ} \mathrm{C}$, the wood $\mathrm{AD}$ and OD densities decreased by $26.7 \%$ and $24.9 \%$ respectively. Compared to before treatment, the density was still higher. The cause was that the weight gain during impregnation process was greater than the weight loss due to HT.

The impregnation of boron, MMA monomer and HT and the combination of those three factors gave a statistically significant influence on the density change. The interaction factor between MMA and HT was also significant, while the other combinations were not significant. The result of Duncan analysis explained that the mean densities of test sample applied with boron and MMA were different, and the mean differences between BX and BA were insignificant (both containing 
Flexural Properties of Heat-Treatment Samama (Anthocephalus macrophyllus) Wood Impregnated by Boron and Methyl Metacrylate

Table 1. Density and moisture content of Samama wood before and after treatment

\begin{tabular}{|c|c|c|c|c|c|c|}
\hline \multirow{3}{*}{ Specimen } & \multicolumn{3}{|c|}{ Before Being Treated } & \multicolumn{3}{|c|}{ After Being Treated } \\
\hline & \multicolumn{2}{|c|}{ Density $\left(\mathrm{g} \mathrm{cm}^{-3}\right)$} & \multirow{2}{*}{$\begin{array}{l}\text { MC } \\
(\%) \\
\end{array}$} & \multicolumn{2}{|c|}{ Density $\left(\mathrm{g} \mathrm{cm}^{-3}\right)$} & \multirow{2}{*}{$\begin{array}{l}\text { MC } \\
(\%) \\
\end{array}$} \\
\hline & Air-Dry & Oven-Dry & & Air-Dry & Oven-Dry & \\
\hline Untreated, $90{ }^{\circ} \mathrm{C}$ & $0.42 \pm 0.03$ & $0.39 \pm 0.02$ & $13 \pm 0.34$ & $0.41 \pm 0.03$ & $0.39 \pm 0.03$ & $11 \pm 0.49$ \\
\hline Untreated, $180{ }^{\circ} \mathrm{C}$ & $0.43 \pm 0.00$ & $0.40 \pm 0.01$ & $12 \pm 0.55$ & $0.39 \pm 0.00$ & $0.37 \pm 0.00$ & $6 \pm 0.32$ \\
\hline Untreated, MMA, $90^{\circ} \mathrm{C}$ & $0.43 \pm 0.01$ & $0.40 \pm 0.00$ & $13 \pm 0.70$ & $0.70 \pm 0.05$ & $0.68 \pm 0.05$ & $6 \pm 0.88$ \\
\hline Untreated, MMA, $180{ }^{\circ} \mathrm{C}$ & $0.41 \pm 0.01$ & $0.38 \pm 0.01$ & $12 \pm 0.98$ & $0.52 \pm 0.04$ & $0.51 \pm 0.04$ & $5 \pm 1.17$ \\
\hline $5 \%$ BA, $90{ }^{\circ} \mathrm{C}$ & $0.43 \pm 0.00$ & $0.40 \pm 0.00$ & $12 \pm 0.53$ & $0.42 \pm 0.00$ & $0.39 \pm 0.00$ & $9 \pm 0.76$ \\
\hline $5 \%$ BA, $180{ }^{\circ} \mathrm{C}$ & $0.44 \pm 0.01$ & $0.41 \pm 0.00$ & $13 \pm 0.52$ & $0.45 \pm 0.00$ & $0.40 \pm 0.00$ & $14 \pm 1.05$ \\
\hline $5 \%$ BA, MMA, $90{ }^{\circ} \mathrm{C}$ & $0.41 \pm 0.00$ & $0.38 \pm 0.00$ & $12 \pm 0.92$ & $0.74 \pm 0.01$ & $0.69 \pm 0.02$ & $7 \pm 0.55$ \\
\hline $5 \%$ BA, MMA, $180^{\circ} \mathrm{C}$ & $0.38 \pm 0.01$ & $0.35 \pm 0.01$ & $12 \pm 0.94$ & $0.54 \pm 0.01$ & $0.52 \pm 0.01$ & $6 \pm 1.38$ \\
\hline $5 \% \mathrm{BX}, 90^{\circ} \mathrm{C}$ & $0.38 \pm 0.01$ & $0.35 \pm 0.01$ & $13 \pm 1.11$ & $0.39 \pm 0.00$ & $0.36 \pm 0.01$ & $14 \pm 1.04$ \\
\hline $5 \% \mathrm{BX}, 180{ }^{\circ} \mathrm{C}$ & $0.42 \pm 0.01$ & $0.39 \pm 0.01$ & $13 \pm 0.88$ & $0.41 \pm 0.00$ & $0.38 \pm 0.01$ & $11 \pm 0.52$ \\
\hline $5 \%$ BX, MMA, $90{ }^{\circ} \mathrm{C}$ & $0.41 \pm 0.01$ & $0.38 \pm 0.01$ & $13 \pm 0.28$ & $0.72 \pm 0.04$ & $0.67 \pm 0.04$ & $7 \pm 0.85$ \\
\hline $5 \%$ BX, MMA, $180^{\circ} \mathrm{C}$ & $0.39 \pm 0.01$ & $0.36 \pm 0.01$ & $13 \pm 0.74$ & $0.63 \pm 0.09$ & $0.60 \pm 0.09$ & $7 \pm 0.71$ \\
\hline
\end{tabular}

and not containing monomer). The previous studies explained that almost all types of wood were reported to show the same behavior after heat treatment, i.e. density decrease. Biziks et al. (2019) reported that the density decrease was identical with temperature increase. Perçin et al. (2015) presented the data that Oak (Quercus petraea) wood also had significant density decrease. Other types of wood, such as Paulownia tomentosa, Populus tementiglandulosa and Pinus Densiflora lost their densities up to $10 \%$ (Kim et al., 2018).

\subsection{Moisture content}

The three treatment phases applied to Samama wood, i.e. impregnation with boron, MMA monomer polymerization and heat treatment, were expected to decrease the hygroscopic level of the wood. This was proven by the moisture content (MC) change value presented in Table 1 . The mean moisture content before treatment was $12.72 \%$. Meanwhile, after the application of boron, MMA monomer and HT, most test samples showed moisture content decrease. In the contrary, the Samama wood treated with 5\% BA, MMA, $180{ }^{\circ} \mathrm{C}$ and 5\% BX, MMA, $90{ }^{\circ} \mathrm{C}$ had increased moisture contents.

The mean moisture content of Samama wood impregnated with MMA and HT lies in 5 - 7\% range. This happened to the Samama wood impregnated or not impregnated with boron. A slightly different result was found in the wood with no monomer. Moisture content decrease was seen in the test sample with no boron and no MMA, yet it showed an increase in two test samples using boron. The analysis of variance result showed that the application of boron, monomer and HT influences MC change. The interaction between factors was also significant, except the interaction between MMA and HT. MMA Polimerization occured at the temperature of $90{ }^{\circ} \mathrm{C}$ that the temperature addition reaching $180{ }^{\circ} \mathrm{C}$ did not influence its hygroscope.

The Samama wood impregnated by MMA with the Heat Treatment $180{ }^{\circ} \mathrm{C}$ without boron experienced a moisture content decrease up to $58 \%$, while that with boron, the moisture content only decreased approxi- 
mately up to $41 \%$. The borax in previous studies was more likely to be hygroscopic than boric acid. On the contrary, monomer forms a bulking agent inside the wood was proven reduce the hygroscopicity. The hygroscopic change in thermal modified wood was a complex process and depended on the sequence of processes applied. During the heat treatment process, the equilibrium moisture content decreased to $50 \%$ compared to the untreated wood (Todaro et al., 2015; Sandberg et al., 2017). As the consequence is the improved dimensional stabilization properties (Park et al., 2016; Chang et al., 2019). Furthermore, the hygroscopic change resulting from HT might also be explained with the cell wall polymerchange. This change may cause a cross-linking, reduction of $\mathrm{OH}$-groups and separation of polymer chain. As a result, the hemicellulose polymer might lose its hygroscopicity.

\subsection{Flexural properties change}

The addition of BA and BX increased Samama's MOE up to $3.3 \%$. The result of Duncan analysis explained that the addition of $\mathrm{BX}$ has greater MOE increase than BA. A significant MOE increase was found in the combined treatment of Boron and monomer. Even the BA and monomer combination produced the highest curve inclination (Fig. 3). Compared to the untreated wood, the difference might be as high as $32.2 \%$. The lowest deflection and load curve inclination was seen in the untreated wood heated at $90{ }^{\circ} \mathrm{C}$.

The heat treatment up to $180{ }^{\circ} \mathrm{C}$ was more likely to reduce Samama wood's MOE, even though some was seen increasing. The wood applied with BA (without monomer) after HT had a mean MOE decrease of $0.7 \%$, while the wood containing $\mathrm{BX}$ seemed to increase by $1.1 \%$. After monomer was added, the MOE decrease of wood with no boron was $15 \%$, and on the other hand, the addition of BX and BA increased MOE value by $0.6 \%$ and $10.5 \%$ respectively. The MOE value difference resulting from MMA and Boron additions was statistically significant, yet it was not the case with HT. The result of ANOVA also showed that the interaction between each factor was not significant. Previous studies conducted by Romagnoli et al. (2015) explained that heat treatment $\left(210{ }^{\circ} \mathrm{C}, 2\right.$ hours) reduced Modulus of Rupture (MOR) value of Douglas Fir and Corsican Pine woods, yet the Modulus of Elasticity
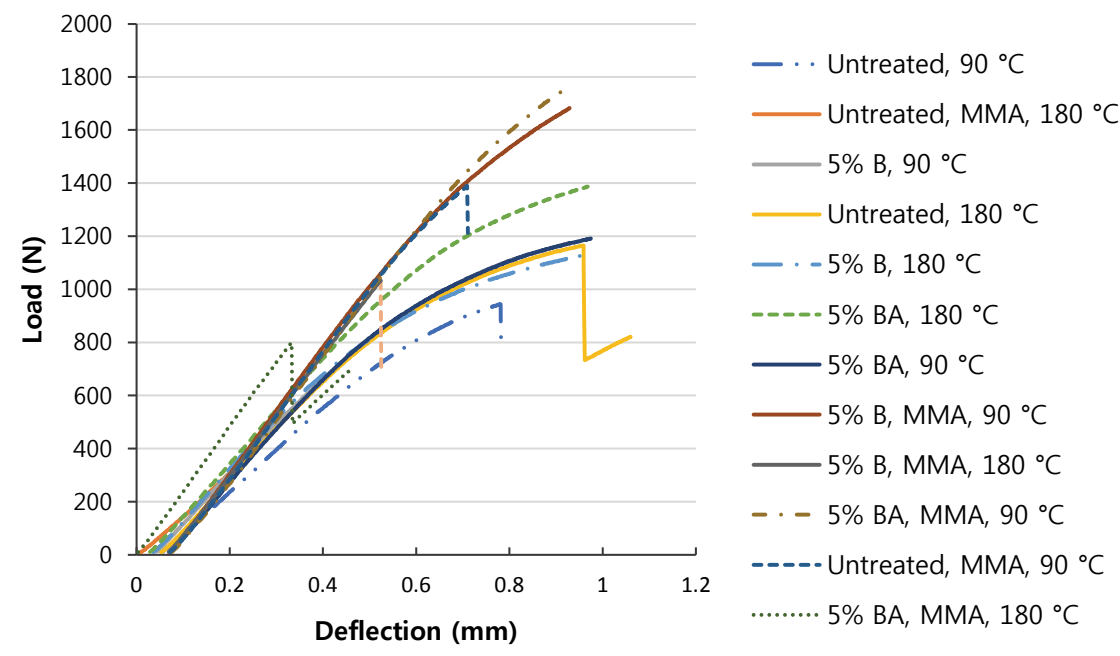

Fig. 4. Load and deflection curves for Samama Wood before and after Treatment. 
Flexural Properties of Heat-Treatment Samama (Anthocephalus macrophyllus) Wood Impregnated by Boron and Methyl Metacrylate

(MOE) value of Corsican Pine wood increased instead. Moreover, Missio et al. (2016) explained that the weight loss of Eucaliptus grandis wood caused by HT by $4 \%$ still allowed the MOE to increase, yet if it exceeded it, what happen would be the opposite.

In addition to changing the Samama's MOE value, heat treatment at $180{ }^{\circ} \mathrm{C}$ also changed MOR value (Table 2). After HT, the mean MOR of Samama containing MMA only ranged between $39 \mathrm{MPa}$ and $44 \mathrm{MPa}$ (1833\% lower than the test sample with no MMA). The result of ANOVA showed that HT significantly influenced MOR decrease while the interaction with the other factors was not significant. The result of Duncan analysis places the test sample impregnated with MMA with no boron had the lowest MOR value and the test sample impregnated with BX and BA had better MOR value. Furthermore, no change in MOR in the untreated wood with no-monomer was found. The wood applied with BX without MMA had its MOR decreased by $12 \%$ and, on the contrary, with BA had its MOR increased by $3 \%$. These MOR increase and decrease of Samama wood with no MMA were statistically insignificant.

Table 2. Flexural properties of Samama wood before and after treatment

\begin{tabular}{|c|c|c|}
\hline Specimen & $\begin{array}{l}\mathrm{MOE} \\
(\mathrm{GPa})\end{array}$ & $\begin{array}{l}\text { MOR } \\
(\mathrm{MPa})\end{array}$ \\
\hline Untreated, $90{ }^{\circ} \mathrm{C}$ & $6.0 \pm 0.8^{\mathrm{d}}$ & $59 \pm 6^{\mathrm{cd}}$ \\
\hline Untreated, $180{ }^{\circ} \mathrm{C}$ & $6.2 \pm 0.2^{\mathrm{cd}}$ & $59 \pm 3^{\mathrm{cd}}$ \\
\hline Untreated, MMA, $90^{\circ} \mathrm{C}$ & $7.2 \pm 0.8^{\mathrm{ab}}$ & $65 \pm 1^{\mathrm{abc}}$ \\
\hline Untreated, MMA, $180{ }^{\circ} \mathrm{C}$ & $6.2 \pm 0.8^{\text {cd }}$ & $39 \pm 8^{f}$ \\
\hline $5 \% \mathrm{BA}, 90^{\circ} \mathrm{C}$ & $6.6 \pm 0.5^{\mathrm{bcd}}$ & $62 \pm 3^{\mathrm{bcd}}$ \\
\hline $5 \%$ BA, $180{ }^{\circ} \mathrm{C}$ & $6.5 \pm 0.7^{\mathrm{bcd}}$ & $64 \pm 6^{\text {bcd }}$ \\
\hline $5 \%$ BA, MMA, $90{ }^{\circ} \mathrm{C}$ & $7.2 \pm 1.0^{\mathrm{abc}}$ & $77 \pm 8^{\mathrm{a}}$ \\
\hline $5 \%$ BA, MMA, $180^{\circ} \mathrm{C}$ & $7.9 \pm 0.1^{\mathrm{a}}$ & $46 \pm 7^{\mathrm{ef}}$ \\
\hline $5 \% \mathrm{BX}, 90^{\circ} \mathrm{C}$ & $6.2 \pm 0.4^{\mathrm{cd}}$ & $60 \pm 4^{\mathrm{cd}}$ \\
\hline $5 \% \mathrm{BX}, 180^{\circ} \mathrm{C}$ & $6.2 \pm 0.3^{\mathrm{bcd}}$ & $53 \pm 1^{\mathrm{de}}$ \\
\hline $5 \% \mathrm{BX}, \mathrm{MMA}, 90{ }^{\circ} \mathrm{C}$ & $7.1 \pm 0.8^{\mathrm{abc}}$ & $73 \pm 8^{\mathrm{ab}}$ \\
\hline $5 \%$ BX, MMA, $180^{\circ} \mathrm{C}$ & $7.1 \pm 1.1^{\mathrm{abc}}$ & $43 \pm 1^{\mathrm{ef}}$ \\
\hline
\end{tabular}

Note: The superscript is the result of Duncan analysis
The previous researches had explained that one factor causing MOR value to change after thermal modification was the change in hemicellulose composition. The hemicellulose degradation might reduce MOR value. Gaff et al. (2019) found a high correlation $(r>0.90)$ between MOR and hemicellulose after thermal modification. On the contrary, the determination coefficient between MOR and density was identified as very low $\left(r^{2}<0.1\right)$. The second reason was that Tarmian and Mastouri (2019) explained that HT would also increase cristalinity index. Next, the effect of boron addition with no heat treatment (HT) was also reported to reduce MOE and MOR values (Toker et al., 2009). The MOR decrease resulting from BX addition was reasonable than with BA (Can et al., 2010). The fourth was the change in lignin after HT (Todaro et al., 2015).

\section{CONCLUSION}

The conclusion of this research was that heat treatment degrades Samama wood, even if it was added or not added with monomer. Borax (BX) held the degradation back better than Boric Acid (BA). Borax might also improve the wood hygroscopic properties. In addition to degrading the wood, $\mathrm{HT}$ at $180{ }^{\circ} \mathrm{C}$ also degraded MMA. The combined treatment of BA, MMA and HT $180{ }^{\circ} \mathrm{C}$ resulted in the highest MOE, while the highest MOR was found in the Samama wood impregnated using BA, MMA and HT $90{ }^{\circ} \mathrm{C}$. The differences of this treatment with untreated wood were $32.2 \%$ and $29.4 \%$ respectively. The weight loss during $\mathrm{HT}$ process at $180{ }^{\circ} \mathrm{C}$ was inconsistent, decreasing the flexural properties of Samama, and some of them increase.

\section{REFERENCES}

ASTM 2010. Standard test methods for direct moisture content measurements of wood and wood-base 
materials (ASTM D4442-92). American Society for Testing and Materials, ASTM International, West Conshohocken, Pennsylvania.

Awoyemi, L., Westermark, U. 2005. Effects of borate impregnation on the response of wood strength to heat treatment. Wood Science and Technology 39(6): 484-491.

Biziks, V., Van Acker, J., Militz, H., Grinins, J., Van den Bulcke, J. 2019. Density and density profile changes in birch and spruce caused by thermohydro treatment measured by X-ray computed tomography. Wood Science and Technology 53(2): 491-504.

Bowyer, J.L., Shmulsky, R., Haygreen, J.G. 2007. Forest products and wood science: an introduction. Wiley-Blackwell Publishing, Ames. Iowa(US).

Cahyono, T.D., Ohorella, S., Febrianto, F. 2012. Beberapa Sifat Kimia dan Keawetan Alami Kayu Samama (Antocephallus macrophyllus) terhadap rayap tanah. Ilmu dan Teknologi Kayu Tropis 10(2): 168-178.

Cahyono, T.D., Wahyudi, I., Priadi, T., Febrianto, F., Bahtiar, E.T., Novriyanti, E. 2016. Analysis on Wood Quality, Geometry Factor, and Their Effects on Lathe Check of Samama (Anthocephalus macrophyllus) Veneer. Journal of the Korean Wood Science and Technology 44(2): 828-841.

Cahyono, T.D., Wahyudi, I., Priadi, T., Febrianto, F., Darmawan, W., Bahtiar, E. T., Ohorella, S., Novriyanti, E. 2015. The quality of 8 and 10 years old samama wood (Anthocephalus macrophyllus). J Indian Acad Wood Sci 12(1): 22-28.

Can, A., Yildiz, S., Yildiz, C.Ü., Tomak, D.E. 2010. Effects of boron impregnation and heat treatment on some physical and mechanical properties of spruce and pine wood.

Chang, Y.-S., Han, Y., Eom, C.-D., Jeon, S., Yeo, H. 2019. Hygroscopic Property of Heat Treated Yellow Poplar (Liriodendron tulipifera) Wood. Journal of the Korean Wood Science and Technology 47(6): 761-769.

Chaouch, M., Pétrissans, M., Pétrissans, A., Gérardin, P. 2010. Use of wood elemental composition to predict heat treatment intensity and decay resistance of different softwood and hardwood species. Polymer Degradation and Stability 95(12): 2255-2259.

Esteves, B., Pereira, H. 2008. Wood modification by heat treatment: A review. BioResources 4(1): 370-404.

Gaff, M., Babiak, M., Kačík, F., Sandberg, D., Turčani, M., Hanzlík, P., Vondrová, V. 2019. Plasticity properties of thermally modified timber in bendingThe effect of chemical changes during modification of European oak and Norway spruce. Composites Part B: Engineering 165: 613-625.

Hadi, Y.S., Nurhayati, T., Yamamoto, H. 2007. Ketahanan Kayu Termodifikasi Kimia terhadap Biodeteriorasi: Studi pada Kayu Asap dan Kayu Asetilasi, Bogor (ID).

JAS 2003. Japanese Agricultural Standard for Structural Laminated Veneer Lumber. JAS: SE-11 No. 237. Japanese Agricultural Standar Association, Japan.

Kartal, S., Yoshimura, T., Imamura, Y. 2004. Decay and termite resistance of boron-treated and chemically modified wood by in situ co-polymerization of allyl glycidyl ether (AGE) with methyl methacrylate (MMA). International biodeterioration \& biodegradation 53(2): 111-117.

Kartal, S.N., Hwang, W.-J., Imamura, Y. 2008. Combined effect of boron compounds and heat treatments on wood properties: Chemical and strength properties of wood. Journal of Materials Processing Technology 198(1-3): 234-240.

Kim, Y.K., Kwon, G.J., Kim, A.R., Lee, H.S., Purusatama, B., Lee, S.H., Kang, C.W., Kim, N.H. 2018. Effects of Heat Treatment on the Characteristics of Royal Paulownia (Paulownia tomentosa (Thunb.) Steud.) Wood Grown in Korea. Journal of the 
Flexural Properties of Heat-Treatment Samama (Anthocephalus macrophyllus) Wood Impregnated by Boron and Methyl Metacrylate

Korean Wood Science and Technology 46(5): 511-526.

Missio, A.L., de Cademartori, P.H.G., Mattos, B.D., Santini, E.J., Haselein, C.R., Gatto, D.A. 2016. Physical and mechanical properties of fast-growing wood subjected to freeze-heat treatments. BioResources 11(4): 10378-10390.

Mohared, A., Van Acker, J., Stevens, M. 2002. Effect of protective additives on leachability and efficacy of borate treated wood. IRG/WP 02-30290. IRG Secretariat, Stockholm, Sweden.

Park, Y., Park, J.-H., Yang, S.-Y., Chung, H., Kim, H., Han, Y., Chang, Y.-S., Kim, K., Yeo, H. 2016. Evaluation of physico-mechanical properties and durability of Larix kaempferi wood heat-treated by superheated steam. Journal of the Korean Wood Science and Technology 44(5): 776-784.

Perçin, O., Sofuoglu, S.D., Uzun, O. 2015. Effects of boron impregnation and heat treatment on some mechanical properties of oak (Quercus petraea Liebl.) wood. BioResources 10(3): 3963-3978.

Priadi, T., Sholihah, M., Karlinasari, L. 2019. Water Absorption and Dimensional Stability of Heattreated Fast-growing Hardwoods. Journal of the Korean Wood Science and Technology 47(5): 567-578.

Romagnoli, M., Cavalli, D., Pernarella, R., Zanuttini, R., Togni, M. 2015. Physical and mechanical characteristics of poor-quality wood after heat treatment. IForest 8(6): 884-891.

Salman, S., Pétrissans, A., Thévenon, M.F., Dumarçay, S., Perrin, D., Pollier, B., Gérardin, P. 2014. Development of new wood treatments combining boron impregnation and thermo modification: effect of additives on boron leachability. European Journal of Wood and Wood Products 72(3): 355-365.

Sandberg, D., Kutnar, A., Mantanis, G. 2017. Wood modification technologies-a review. iForestBiogeosciences and Forestry 10(6): 895-908.

Simsek, H., Baysal, E., Peker, H. 2010. Some mechanical properties and decay resistance of wood impregnated with environmentally-friendly borates. Construction and Building Materials 24(11): 2279-2284.

Sites, W., Williams, L. 1997. Performance of borate treated wood coated with water repellants in Caribbean and southern US. Test structures. Proceedings Second International Conference on Wood Protection with Diffusible Preservation and Pesticides.

Tarmian, A., Mastouri, A. 2019. Changes in moisture exclusion efficiency and crystallinity of thermally modified wood with aging. iForest-Biogeosciences and Forestry 12(1): 92-97.

Todaro, L., Rita, A., Negro, F., Moretti, N., Saracino, A., Zanuttini, R. 2015. Behavior of pubescent oak (Quercus pubescens Willd.) wood to different thermal treatments. IForest 8(6): 748-755.

Toker, H., Baysal, E., Simsek, H., Senel, A., Sonmez, A., Altınok, M., Ozcıfcı, A., Yapıcı, F. 2009. Effects of some environmentally-friendly fire-retardant boron compounds on modulus of rupture and modulus of elasticity of wood. Wood Research (Bratislava) 54(1): 77-88.

Wang, Q., Wang, W., Winandy, J.E. 2005. Effects of a new GUP-B fire retardant on mechanical properties of Korean pine when exposed to elevated temperature. Forest Products Journal 55(12): 214.

Yalinkilic, M.K., Tsunoda, K., Takahashi, M., Gezer, E.D., Dwianto, W., Nemoto, H. 1998. Enhancement of biological and physical properties of wood by boric acid-vinyl monomer combination treatment. Holzforschung 52(6): 667-672. 